\title{
Distiller's dried grain with solubles (Zea mays $L)$ in the diet of sheep reared in the tropical region of Brazil: ingestive behavior and physiological parameters
}

\author{
Grãos secos de destilaria com solúveis (Zea mays $\mathrm{L}$ ) na dieta \\ de ovinos criados na região tropical do Brasil: comportamento \\ ingestivo e parâmetros fisiológicos
}

\author{
Luiz Juliano Valério Geron ${ }^{1 *}$; Sílvia Cristina de Aguiar ${ }^{1}$; Jocilaine Garcia ${ }^{1}$; \\ Lúcia Maria Zeoula²; Kallynka Samara Martins Coelho³; Ilda de Souza Santos ${ }^{3}$; \\ José Wilson Pires Carvalho'; Alexandre Lima de Souza'; \\ Anderson de Moura Zanine ${ }^{5}$, Leomar Custodio Diniz ${ }^{3}$
}

\begin{abstract}
This study aimed to evaluate the effects of inclusion of different levels of distiller's dried grain with solubles (DDGS) in the diet of sheep raised in the tropical region of Brazil on ingestive behavior and physiological parameters. We used four sheep with mean body weight (BW) of $25 \pm 2 \mathrm{~kg}$, distributed in a Latin square design, with four periods, and four DDGS inclusion levels $(0,8,16$, and 24\%). The sheep were placed in metabolism cages, and received two meals per day. The data on ingestive behavior and physiological parameters of the sheep were analyzed with analysis of variance (ANOVA), and the observed differences were tested using regression equations at $5 \%$ probability. The inclusion of DDGS levels in sheep diets did not change the time spent on ingestive behavior, such as dry matter intake (DMI), rumination (RUM), resting (RES), water intake (WAI), and other activities (OAC) expressed in minutes. However, during the night period, there was an increase $(\mathrm{p}<0.05)$ in the time spent ruminating in relation to the daytime period. However, there was a reduction $(p<0.05)$ in the time spent on the activities of RES and WAI of the sheep. The inclusion of DDGS in sheep rations did not change ( $p>$ $0.05)$ the physiological parameters measured. However, we found that the afternoon period influenced $(\mathrm{p}<0.05)$ the physiological parameters evaluated, such as body temperature of the front (BTF), body temperature of the rear (BTR), rectal temperature (RET), and respiratory frequency (REF), which were higher in relation to the values observed in the morning. Thus, we conclude that the inclusion of up to $24 \%$ of dried distillery grains with solubles in the feeding of sheep in the tropical region of Brazil does not alter the ingestive behavior and physiological parameters of sheep. However, sheep raised in confinement in the tropical region of Brazil spent more time ruminating at night. During the day, sheep spent more time on resting activities and water intake. In addition, sheep raised in a tropical environment need to be monitored for thermal stress during the afternoon, due to the increase in rectal temperature and respiratory frequency. In addition, sheep raised in a tropical environment require greater monitoring of thermal stress during the afternoon, due to the elevation of physiological parameters such as rectal
\end{abstract}

\footnotetext{
1 Profs., Universidade do Estado de Mato Grosso, UNEMAT, Pontes e Lacerda, MT, Brasil. E-mail: ljgeron@yahoo.com.br; scaguiar@unemat.br; jo@unemat.br; jwilson@unemat.br

2 Profa, Universidade Estadual de Maringá, UEM, Maringá, PR, Brasil. E-mail: 1mzeoula@uem.br

3 Discentes, UNEMAT, Pontes e Lacerda, MT, Brasil. E-mail: coelho-ksm@hotmail.com; ildasouza20@hotmail.com; leomarfig@ hotmail.com

4 Prof., Universidade Federal de Mato Grosso, UFMT, Cuiabá, MT, Brasil. E-mail: alexandre@ufmt.br

5 Prof., Universidade Federal do Maranhão, UFMA, Chapadinha, MA, Brasil. E-mail: anderson.zanini@ibest.com.br

* Author for correspondence
} 
temperature and respiratory frequency in this period.

Key words: Dry matter intake. Respiratory frequency. Rumination. Resting. Rectal temperature.

\section{Resumo}

Objetivou-se avaliar a inclusão de níveis crescentes de grãos secos de destilaria com solúveis (GSDS) na dieta de ovinos criados na região tropical do Brasil sobre o comportamento ingestivo e os parâmetros fisiológicos. Foram utilizados quatro ovinos com peso corporal (PC) médio de $25 \pm 2 \mathrm{~kg}$, distribuídos em delineamento em quadrado latino, com quatro períodos e quatro níveis de inclusão dos GSDS $(0$, 8,16 e $24 \%$ ). Os ovinos foram alocados em gaiolas de metabolismo e receberam duas refeições por dia. Os dados de comportamento ingestivo e parâmetros fisiológicos dos ovinos foram submetidos à análise de variância e as diferenças observadas foram testadas utilização equação de regressão a $5 \%$ de probabilidade. A inclusão dos níveis de GSDS na alimentação de ovinos não alterou ( $>00,05)$ o tempo despendido para as atividades de comportamento ingestivo como, consumo de matéria seca (CMS), ruminação (RUM), ócio (OCI), consumo de água (CAG) e outras atividades (OAT) expressos em minutos. Porém, durante o período noturno houve aumento $(\mathrm{p}<0,05)$ no tempo utilizado para RUM em relação ao período diurno, no entanto, houve redução $(\mathrm{p}<0,05)$ nas atividades de OCI e CAG dos ovinos. A inclusão de GSDS nas rações de ovinos não alterou $(p>0,05)$ os parâmetros fisiológicos. Contudo, foi observado que o período da tarde influenciou $(\mathrm{p}<0,05)$ os parâmetros fisiológicos avaliados, como a temperatura corporal do dianteiro (TCD), temperatura corporal do traseiro (TCT), temperatura retal (TER) e frequência respiratória (FRE), os quais foram superiores em relação aos valores observados no período da manhã. Desta maneira, conclui-se que a inclusão de até $24 \%$ de grãos secos de destilaria com solúveis na alimentação de ovinos na região tropical do Brasil, não altera o comportamento ingestivo e os parâmetros fisiológicos. Porém, os ovinos criados em confinamento em região tropical do Brasil apresentam maior tempo para a atividade de ruminação durante a noite. Durante o dia ocorre maior utilização de tempo para as atividades de ócio e consumo de água. Além disso, os ovinos criados em ambiente tropical necessitam de maior atenção com ao estresse térmico durante o período da tarde, devido ao aumento da temperatura retal e a frequência respiratória.

Palavras-chave: Consumo de matéria seca. Frequência respiratória. Ruminação. Ócio. Temperatura retal.

\section{Introduction}

One of the challenges related to livestock farming in the central west region of Brazil is the production of food of good nutritional value that meets the nutritional needs of animals in the dry season (shortage of bulky foods). Therefore, food alternatives may promote the reduction of the use of conventional food concentrates (corn grains and soybean meal), and enable the use of alternative ingredients with the desired nutritional characteristics found between the production source and the place of consumption (GERON et al., 2015).

Once possible alternative ingredient that may be used in animal feed is the residue obtained after the processing of corn grain for the production of ethanol in Brazilian distilleries. This ingredient is referred to as distiller's dried grain with solubles (DDGS). The bromatological composition of DDGS is as follows: $87.0 \%$ to $93.0 \%$ dry matter (DM); $28.1 \%$ to $32.9 \%$ crude protein $(\mathrm{CP}) ; 8.2 \%$ to $16.5 \%$ of ethereal extract (EE), $19.7 \%$ to $49.5 \%$ of neutral detergent fiber (NDF), and $69.6 \%$ to $78.0 \%$ of total digestible nutrients (TDN) (NUEZ-ORTÍN; YU, 2009; SALIM et al., 2010; GERON et al., 2017b). Studies are needed to determine appropriate levels of DDGS that could be included in ruminant rations (GERON et al., 2017a).

According to Bremm et al. (2008), the ingestive behavior of animals allows for the definition of adequate food management strategies, which 
provides an ability to positively influence production results.

According to Yang et al. (2001), the ingestive behavior of sheep in confinement is correlated with forage intake and/or concentrated roughage ratio, nutritional value of food, palatability, particle size, and dietary form. Neutral detergent fiber (NDF) is considered the first factor that affects this activity, since it interferes directly in ruminal functioning.

Animal feeding studies have shown that animals can recognize the energy value of food and can assess the energy cost to obtain food. Having the choice, animals usually prefer to continue eating foods that are they are accustomed to (MILLEN et al., 2013; RIBEIRO et al., 2011).

The rumination and rest periods between meals, their duration and their distribution pattern are influenced by ingestion activities (DESWYSEN et al., 1993; FISCHER et al., 1997a, FISCHER et al., 1997b).

Stacked animals spend about two hours consuming energy-rich foods, and may spend more than six hours consuming foods with low energy content (CARVALHO et al., 2006). Similarly, the time spent ruminating is influenced by the nature of the diet, and is probably proportional to the cell wall content of the roughage. Therefore, the greater the proportion of roughage in the diet, the longer the time spent ruminating (VAN SOEST, 1994). A study carried out by Carvalho et al. (2006) demonstrated that an increase in rest periods occurred as a function of the reduction of fiber contents of the rations.

According to the literature, among the physiological parameters, changes in rectal temperature and/or respiratory rate have been the two parameters most frequently used as measures of animal comfort, and to measure the efficacy of the production environment. In general, the ambient temperature is the climatic element that most influences these two physiological variables, following, in order of importance, solar radiation, relative humidity, and air movement
(HEMSWORTH et al., 1995; SILVA JÚNIOR, et al., 2014).

According to a review by Ferreira et al. (2009), factors such as age, season, production level, food and water intake, physical activity, and the production environment can naturally change physiological parameters such as rectal temperature, heart and respiratory rate, parameters and rate of sweating.

The objective of the current study was to evaluating the inclusion of levels of distiller's dried grain with solubles (DDGS) in the diet of sheep raised in the tropical region of Brazil on ingestive behavior and physiological parameters.

\section{Material and Methods}

The study was conducted at the Pontes and Lacerda University Campus, in the Center for Animal Metabolism (Setor de Metabolismo Animal, SEMA) and the Laboratory for Food Analysis and Animal Nutrition (Análise de Alimentos e Nutrição Animal, LAANA), belonging to the Universidade do Estado de Mato Grosso (UNEMAT), located at $15^{\circ} 19^{\prime} 05^{\prime \prime / ~} 59^{\circ} 13$ ' $26^{\prime}$ ", and at an altitude of 295 meters above sea level. According to a description by Geron et al. (2013), the climate of the study site, in the Alto Guaporé Valley, Mato Grosso (MT) is classified as tropical continental, and the climate is alternately wet and dry type Aw according to Koppen.

Four sheep without bred were used, with mean body weight $(\mathrm{BW})$ of $25 \pm 2 \mathrm{~kg}$. The sheep were housed in metabolism cages, containing feeders and individual drinking fountains. The sheep were dewormed fifteen days before the beginning of the experimental period with ivermectin, following the manufacturer's (Merial Saúde Animal - Ltda) instructions.

The experimental design was a $4 \times 4$ Latin square, with four periods and four inclusion levels of distiller's dried grain with solubles (DDGS - 0, 8, 
16 and 24\% in the total ration). This experimental design was used to evaluate the effects of DDGS on ingestive behavior and physiological parameters of sheep raised in the tropical region of Brazil.

The distiller's dried grain with solubles (DDGS) was composed of Zea mays L (corn grain), obtained from an ethanol and sugar distillery (USIMAT) located in the municipality of Campos de Júlio MT, approximately $250 \mathrm{~km}$ from the Pontes and
Lacerda University Campus - UNEMAT and 450 $\mathrm{km}$ from the capital of Mato Grosso, Cuiabá.

The concentrated feed used in the preparation of the experimental rations consisted of grain corn, soybean meal, and distiller's dried grain with solubles (Zea mays L.). The roughage provided to the sheep was corn silage. The bromatological composition of the experimental foods is presented in Table 1.

Table 1. Bromatological composition of feed used in rations containing different levels of distiller's dried grain with solubles (DDGS).

\begin{tabular}{lccccccccc}
\hline Foods & \multicolumn{8}{c}{ \% of nutrients expressed in DM } \\
\hline & \% DM & OM & CP & EE & NDF & ADF & TCH & NFC & TDN $^{1}$ \\
\hline CS & 29.33 & 93.36 & 7.54 & 3.59 & 54.38 & 28.58 & 82.23 & 27.85 & 61.30 \\
GC & 90.99 & 97.38 & 9.20 & 5.85 & 14.05 & 6.47 & 82.33 & 68.28 & 86.03 \\
SM & 91.29 & 92.69 & 49.26 & 2.19 & 15.37 & 10.97 & 41.24 & 25.87 & 80.73 \\
DDGS & 90.04 & 98.00 & 34.41 & 4.47 & 48.80 & 15.37 & 59.11 & 10.31 & 78.50 \\
\hline
\end{tabular}

CS: corn silage; GC: ground corn; SM: soybean meal; DM: dry matter; OM: organic matter; CP: crude protein; EE: ethereal extract; NDF: neutral detergent fiber; ADF: acid detergent fiber; TCH: total carbohydrates; NFC: Non-fibrous carbohydrates and TDN: total digestible nutrients - obtained from the literature (VALADARES FILHO et al., 2010; SPHIES et al., 2002).

The proportion of roughage used in the provide on average $13.5 \%$ of crude protein and experimental rations was $65 \%$ of corn silage and $68.5 \%$ of total digestible nutrients, as recommended $35 \%$ of concentrate. The rations were balanced to by the NRC (2007) (see Table 2).

Table 2. Percentage and bromatological composition of the rations containing different of distiller's dried grain with solubles (DDGS).

\begin{tabular}{lcccc}
\hline & \multirow{2}{*}{ Foods } & \multicolumn{3}{c}{ Levels of DDGS in experimental rations (\%) } \\
\cline { 2 - 5 } & 0 & 8 & 16 & 24 \\
\hline Corn silage (CS) & 65.0 & 65.0 & 65.0 & 65.0 \\
Ground corn (GS) & 21.5 & 18.0 & 14.5 & 11.0 \\
Soybean meal (SM) & 13.5 & 9.0 & 4.5 & 0.0 \\
Distiller's dried grain with solubles (DDGS) & 0.0 & 8.0 & 16.0 & 24.0 \\
Total & 100.0 & 100.0 & 100.0 & 100.0 \\
\hline \multicolumn{7}{c}{ Bromatological composition of feed containing DDGS } \\
\hline Dry matter (DM) & 50.95 & 50.86 & 50.77 & 50.69 \\
Organic matter (MO) \% & 94.13 & 94.39 & 94.66 & 94.92 \\
Crude protein (CP) \% & 13.53 & 13.74 & 13.96 & 14.17 \\
Ethereal extract (EE) \% & 3.89 & 3.94 & 4.00 & 4.05 \\
& & & & continue
\end{tabular}


continuation

\begin{tabular}{lllll} 
Neutral detergent fiber (NDF) \% & 40.44 & 43.16 & 45.88 & 48.61 \\
Acid detergent fiber (ADF) \% & 21.45 & 21.96 & 22.47 & 22.98 \\
Total carbohydrates (TCH) \% & 76.72 & 76.71 & 76.70 & 76.69 \\
Non-fibrous carbohydrates (NFC) \% & 36.27 & 33.55 & 30.82 & 28.09 \\
Total digestible nutrients (TDN)\% & 69.24 & 68.88 & 68.51 & 68.15 \\
\hline
\end{tabular}

Sheep had access to water through individual drinking fountains. Daily, $10 \mathrm{~g}$ of mineral mixture was added directly to the experimental concentrates provided to each sheep at the time of the feed, i.e. twice daily ( $5 \mathrm{~g}$ salt of portion $^{-1}$ animal $\left.^{-1}\right)$.

The chemical composition of the commercial mineral salt used in the current study was $120 \mathrm{~g} \mathrm{Ca}$ $\mathrm{kg}^{-1} ; 85 \mathrm{~g}$ of $\mathrm{P} \mathrm{kg}^{-1} ; 16 \mathrm{~g}$ of $\mathrm{Sk}^{-1} ; 148 \mathrm{~g} \mathrm{Na} \mathrm{kg}^{-1} ; 50$ $\mathrm{mg} \mathrm{Co} \mathrm{kg}{ }^{-1} ; 500 \mathrm{mg} \mathrm{Cu} \mathrm{kg}^{-1} ; 16 \mathrm{mg}$ of $\mathrm{Se} \mathrm{kg}^{-1}$ and 4,800 $\mathrm{mg}$ of $\mathrm{Zn} \mathrm{kg}^{-1}$.

The experimental rations were provided to the sheep in two meals a day, at $06 \mathrm{~h} 00$ and $18 \mathrm{~h} 00$ at will, so that there were approximately $10 \%$ of leftovers. Monitoring of leftovers was performed daily, before the first treatment of the day.

The sheep were kept under evaluation for 80 days to collect data on intake, ingestive behavior, and physiological parameters, and the experiment was divided into four experimental periods, with a duration of 20 days. This included 14 days for adaptation of the animals, and six days for collection of samples of leftover and foods. In the period of adaptation and data collection, animal management was performed as described by Geron et al. (2015).

Throughout the experimental period, artificial lighting was maintained during the night, to allow the sheep to adapt to the conditions during the days of data collection on ingestive behaviors. The sheep were observed visually to evaluate the variables associated with ingestive behavior. Observations were recorded every five minutes for 24 hours, to determine the time spent on the different activities associated with ingestive behavior (JOHNSON; COMBS, 1991).
In order to collect data on the variables of ingestive behavior, the recorded data were tabulated in a spreadsheet, with separate spreadsheets used for each sheep (GERON et al., 2014).

The behaviors (activities) observed in sheep were dry matter intake (DMI), rumination (RUM), resting (RES), water intake (WAI), and other activities (OAC) that did not fit into the others described previously (e.g., playing, scratching, mineral salt intake, etc.), which were measured $24 \mathrm{~h} \mathrm{day}^{-1}$, during four non-consecutive days. The total period of evaluation of the daily ingestive behavior was divided in two, where the first period lasted from $7 \mathrm{~h} 00$ am to $6 \mathrm{~h} 59 \mathrm{pm}$. (daytime), and the second period from $7 \mathrm{~h} 00 \mathrm{pm}$. to $6 \mathrm{~h} 59 \mathrm{am}$. (night).

The total time of each activity observed in the different periods (diurnal and nocturnal) was obtained by summing the total number of times that each sheep was engaged in a certain behavior, according to the recommendations of Geron et al. (2014).

The physiological parameters evaluated were respiratory frequency (REF), rectal temperature (RET), body temperature of the front (BTF), and body temperature of the rear (BTR). These parameters were measured during three days in each experimental period, at the hours of $07 \mathrm{~h} 00,11 \mathrm{~h} 00$, $13 \mathrm{~h} 00$ and 17h00, as described by Silva et al. (2015). The RET was measured with a clinical thermometer inserted in the rectum of the animal for two minutes. The REF was recorded by visual observations of how many times the "void" of the animal inflated and deflated in 15 seconds, and the result was multiplied by four, to obtain the respiratory rate per 
minute. The BTF and BTR were obtained by means of a digital infrared thermometer, the BTF in the region of each sheep's palette, and the BTR in the thigh.

The environmental variables recorded during the experimental period were the ambient temperature (AT), dry bulb temperature (DBT), and wet bulb temperature (WBT). The AT was obtained by means of a taco type thermometer, and DBT and WBT were measured using a dry bulb and a wet bulb thermometer, respectively. The maximum and minimum temperature measurements were obtained by using the maximum and minimum temperature thermometer (VERÍSSIMO et al., 2009).

The temperature measurements were performed during three days of each experimental period. Relative air humidity was calculated based on the BSCS/INEC (1970) formula, where the relative air humidity (\%) was obtained by computing $\Delta \mathrm{T}$ (saturation deficit) $=\mathrm{T}_{\mathrm{D}}-\mathrm{T}_{\mathrm{w}}$, where $\mathrm{T}_{\mathrm{D}}$ is the temperature of the dry bulb minus the temperature of the wet bulb $\left(\mathrm{T}_{\mathrm{w}}\right)$. The data of wet bulb temperature and saturation deficit $(\Delta T)$ were interpolated in the saturated vapor pressure table as a function of temperature to obtain the relative humidity of the air (\%).

The temperature and humidity index (THI) was calculated from the model proposed by Thom (1959), and using the following equation: $\mathrm{THI}=0.72 \mathrm{x}$ (DBT $+\mathrm{WBT})+40$, where DBT $=$ dry bulb temperature; and $\mathrm{WBT}=$ wet bulb temperature. For evaluation of the THI, the classification by Souza et al. (2010) was used, where THI $<74$ is considered as animals being within the appropriate thermal comfort; 74 $\leq$ THI $<79$ is considered a hot environment, in which thermal discomfort begins, causing health problems and reduced performance; $79 \leq \mathrm{THI}<84$ is considered a very hot environmental condition, indicating danger, and which could have serious consequences for health, requiring precautions to avoid production losses; and THI $>84$ indicates extremely hot conditions, with very serious health risks, which may require urgent steps to be taken to avoid losing the flock.

Samples of food and leftovers were oven dried at $55{ }^{\circ} \mathrm{C}$ for $72 \mathrm{~h}$ and processed in a knife mill using a $1 \mathrm{~mm}$ sieve screen, and then homogenized in equal amounts on a dry weight basis to form composite samples of leftovers per animal period ${ }^{-1}$ ration $^{-1}$.

The final dry matter (DM) contents of the analyzed samples were obtained through the use of a drying oven and sterilization at $130{ }^{\circ} \mathrm{C}$ until the samples reached constant weight. The nitrogen content of the food and leftovers was obtained by the semimicro-Kjeldahl method, using 6.25 as conversion factor for crude protein (CP). The mineral matter (MM) was determined by incineration in a muffle at $600{ }^{\circ} \mathrm{C}$. The organic matter content (OM) was estimated by calculating the difference between the total mater and the mineral matter (100 - MM), and the content of ethereal extract (EE) was determined by extraction with petroleum ether (SILVA; QUEIROZ, 2002).

The determination of neutral detergent fiber (NDF) and acid detergent fiber (ADF) of foods and leftovers was performed according to Van Soest et al. (1991), without the use of sulfite, and without correcting the values of NDF and FDA with respect to the mineral content of the fiber. The determination of the total carbohydrates $(\mathrm{TCH})$ of foods and leftovers was obtained by the equation: $\mathrm{TCH}=100-(\% \mathrm{CP}+\% \mathrm{EE}+\% \mathrm{MM})($ SNIFFEN et al., 1992). The non-fibrous carbohydrate (NFC) content of food and leftovers was determined by the equation: $\mathrm{NFC}=100-(\mathrm{CP}+\mathrm{NDF}+\mathrm{EE}+\mathrm{MM})$ according to Sniffen et al. (1992).

The variables studied (ingestive behavior and physiological parameters) were analyzed with ANOVA (analysis of variance) using SAEG software (UFV, 2007). Effects were considered significant at $p<0.05$. When significance was verified for DDGS inclusion levels in the experimental rations, regression analysis was performed, considering the linear and quadratic effect at $\mathrm{p}<0.05$. 
For the ingestive behavior data and physiological parameters, were considered the subdivisions of the plots, considering daytime and night time evaluation in the ingestive behavior, and morning and afternoon in the physiological parameters of ovine fed with DDGS, for the periods evaluated were compared by the test tukey at 0.05 probability (SOUZA et al., 2016).

\section{Results and Discussion}

The average ambient temperature during the evaluation of the ingestive behavior of sheep fed with DDGS was above $29.00{ }^{\circ} \mathrm{C}$. The minimum temperature was $23.36{ }^{\circ} \mathrm{C}$, and the maximum temperature was $35.19{ }^{\circ} \mathrm{C}$ (Table 3). The temperature and humidity index (THI) was $77.43 \%$ in the morning in the west region of Mato Grosso, indicating a warm environment, which may cause thermal discomfort in the animals (Table 3). However, during the afternoon, the THI was $88.08 \%$, indicative of extremely hot environment, posing a very serious risk to sheep health, with possible effects on productive and reproductive performance. In general, the mean value of the THI during the $24 \mathrm{~h}$ period was $80.25 \%$, indicating a warm environment in which thermal discomfort begins, and which can cause health problems and reduce animal performance (SOUZA et al., 2010).

Table 3. Ambient temperature and relative humidity of the air during the experimental period of sheep fed with rations containing the different levels of distiller's dried grain with solubles (DDGS).

\begin{tabular}{lccccccc}
\hline Period & \multicolumn{7}{c}{ Climatic variables of the environment } \\
\hline & AT & AT min & AT max & DBT & WBT & RH do air \% & THI \\
\hline Morning & 26.17 & - & - & 28.08 & 23.33 & 65.00 & 77.43 \\
Afternoon & 31.93 & - & - & 32.25 & 26.92 & 62.00 & 88.08 \\
Average & 29.54 & 23.36 & 35.19 & 30.17 & 25.12 & 64.00 & 80.25 \\
\hline
\end{tabular}

AT: Ambient temperature; AT min: minimum ambient temperature; AT max: maximum ambient temperature; DBT: dry bulb temperature; WBT: wet bulb temperature; RH: relative humidity of the air in \% e THI: temperature and humidity index.

The inclusion of $0,8,16$, and $24 \%$ DDGS did not affect $(p>0.05)$ the time spent on the different ingestive behavior activities in the $24 \mathrm{~h}$ period (Table 4). The average amount of time spent on dry matter intake (DMI); rumination (RUM); resting (RES); water intake (WAI) and other activities (OAC) was $266 \mathrm{~min}, 536 \mathrm{~min}, 577 \mathrm{~min}, 17 \mathrm{~min}$, and $44 \mathrm{~min}$, respectively. 
Table 4. Ingestive behavior (expressed in minutes) of sheep fed different levels of distiller's dried grain with solubles (DDGS) evaluated in the period of 24.

\begin{tabular}{|c|c|c|c|c|c|c|}
\hline \multirow[t]{2}{*}{ Activity } & \multicolumn{4}{|c|}{ Levels of DDGS in experimental rations (\%) } & \multirow[t]{2}{*}{ Regression } & \multirow[t]{2}{*}{$\% \mathrm{CV}$} \\
\hline & 0 & 8 & 16 & 24 & & \\
\hline DMI (min.) & 278 & 235 & 268 & 285 & $Y=266$ & 19.18 \\
\hline RUM (min.) & 531 & 540 & 526 & 548 & $Y=536$ & 12.08 \\
\hline RES (min.) & 565 & 605 & 601 & 536 & $Y=577$ & 17.34 \\
\hline WAI (min.) & 18 & 15 & 14 & 20 & $\mathrm{Y}=17$ & 41.57 \\
\hline OAC (min.) & 49 & 45 & 31 & 51 & $Y=44$ & 45.83 \\
\hline
\end{tabular}

$\mathrm{DMI}$ = dry matter intake; RUM = rumination; RES: resting; WAI: water intake; and OAC: other activities. CV: coefficient of variation.

A study conducted by Cirne et al. (2014), which evaluated ingestive behavior of feedlot sheep fed diets containing different levels of crude protein, found that DM intake activity (expressed in minutes) decreased linearly in relation to the crude protein increase in total rations. These authors observed that, for diets containing $14 \%$ crude protein, the mean amount of time spent on DMI, RUM, and RES was $223 \mathrm{~min}, 122 \mathrm{~min}$, and $1090 \mathrm{~min}$, respectively. It is likely that the higher NDF content of the rations of the current study resulted in a longer mean time spent ruminating (RUM, $536 \mathrm{~min}$ ) compared to the study by Cirne et al. (2014), which included mean NDF of $24 \%$ in the total ration, and in which sheep spent less time ruminating $(122 \mathrm{~m})$. Although NDF levels in the current study ranged from $40 \%$ to $49 \%$ in diets with the inclusion of DDGS, there was no effect on rumination time, probably because the increase in NDF content in the diets came from nonforage fiber, i.e. the DDGS.

A study by Mousquer et al. (2013), which evaluated the ingestive behavior of sheep fed elephant grass silage, found that sheep receiving diets including this feed, without additive or containing different additives (coffee husk, cocoa meal, and cassava meal at $15 \%$ of DM), did not change the time spent on DMI, RUM, and RES activities, with mean values of $310 \mathrm{~min}, 480 \mathrm{~min}$, and $650 \mathrm{~min}$, respectively. In this study, values similar to those observed by Mousquer et al. (2013) are shown in Table 4.

According to Geron et al. (2017b), the inclusion of different levels of DDGS in sheep feed did not alter $(p>0.05)$ the intake of DM expressed as $g$ animal $^{-1}$ day $^{-1}$ and percentage of body weight (\% BW). According to these authors, the mean DM intake in sheep fed diets containing different levels of DDGS was $661.90 \mathrm{~g}$ animal $^{-1}$ day $^{-1}$. The experimental rations consisted of a mean NDF content of $44.52 \%$, with a range of variation of nine percentage units (40.0\% to $49.0 \%$ NDF) among rations containing DDGS. The authors reported that this increase in NDF content of DDGS-containing diets was correlated with NDF from other nonforage sources (concentrated feed), mainly to DDGS. These facts are in agreement with the values observed in relation to the time spent on the activities of DMI, RUM, RES, WAI and OAC.

According to Hubner et al. (2008), an increase in the NDF content in total sheep rations altered the ingestive behavior in a quadratic way for the time spent on DMI, RUM, RES, and WAI. These authors reported that the time spent on DMI and RUM increased as the diet NDF level increased from 34\% to $52 \%$ in the total ration, with maximum points estimated at $43.5 \%$ NDF. However, the time sheep spent on RES also had an estimated minimum point when sheep were fed diets containing 43.5\% NDF. 
Regardless of DDGS inclusion levels in ovine rations, there was an effect $(p<0.05)$ of period (diurnal/nocturnal) on the time spent on RUM, RES, and WAI activities. However, these periods did not affect $(p>0.05)$ the time spent on DMI and OAC (Table 5). Meal provision may have contributed to the results regarding time spent on DMI within the assessment period (day and night), since meals were provided at the beginning of each trial period, i.e. at $06 \mathrm{~h} 00 \mathrm{am}$ and $6 \mathrm{~h} 00 \mathrm{pm}$. In addition, the similar consumption among diets containing different levels of DDGS may have contributed to this observation.

The sheep spent more $(\mathrm{p}<0.05)$ time ruminating in the night time (320 min), than during the daytime period (234 min, Table 5). It is possible that this variation is related to the ambient temperature, which was more pleasant during the night period. In addition, during the day time, the temperature and humidity index (THI) was much higher than during the night (Table 3), which supports the data obtained, since, during the day, sheep spent more time on water intake, and less time on activities which would generate heat by accelerating metabolism. In addition, RUM activity is probably inversely correlated with the time spent on DMI and RES activities. Sheep have a gregarious habit of defending against predators, which consequently reduces the time engaged in activities such as searching for food, and increases the time spent on activities such as rumination and/or resting, especially in the nocturnal period.

A study by Michailoff et al. (2015), which evaluated the ingestive behavior and physiological parameters of confined sheep, obtained an average value of $300 \mathrm{~min}$ in $12 \mathrm{~h}$ (daytime) for RES activity. In the current study, values of 307 min were found for the RES variable, in the diurnal period (12 h), similar to the values reported by Michailoff et al. (2015).

Table 5. Ingestive behavior (expressed in minutes) of sheep fed with different levels of distiller's dried grain with solubles (DDGS) according to the diurnal and nocturnal periods.

\begin{tabular}{|c|c|c|c|c|c|c|c|}
\hline \multirow[t]{2}{*}{ Activity } & \multirow[t]{2}{*}{ Period } & \multicolumn{4}{|c|}{ Levels of DDGS in experimental rations (\%) } & \multirow[t]{2}{*}{ Average } & \multirow[t]{2}{*}{$\% \mathrm{CV}$} \\
\hline & & 0 & 8 & 16 & 24 & & \\
\hline \multirow[t]{2}{*}{ DMI } & Daytime & 150 & 114 & 154 & 160 & $\mathrm{Y}=145 \mathrm{a}$ & 27.62 \\
\hline & Night & 128 & 121 & 114 & 125 & $\mathrm{Y}=122 \mathrm{a}$ & 27.62 \\
\hline \multirow[t]{2}{*}{ RUM } & Daytime & 229 & 218 & 265 & 226 & $\mathrm{Y}=234 \mathrm{a}$ & 19.68 \\
\hline & Night & 303 & 323 & 261 & 321 & $\mathrm{Y}=302 \mathrm{~b}$ & 19.68 \\
\hline \multirow[t]{2}{*}{ RES } & Daytime & 306 & 356 & 271 & 295 & $\mathrm{Y}=307 \mathrm{~b}$ & 24.89 \\
\hline & Night & 259 & 249 & 330 & 241 & $\mathrm{Y}=270 \mathrm{a}$ & 24.89 \\
\hline \multirow[t]{2}{*}{ WAI } & Daytime & 11 & 11 & 10 & 15 & $\mathrm{Y}=12 \mathrm{~b}$ & 68.66 \\
\hline & Night & 6 & 4 & 4 & 5 & $\mathrm{Y}=5 \mathrm{a}$ & 68.66 \\
\hline \multirow[t]{2}{*}{ OAC } & Daytime & 24 & 21 & 20 & 24 & $\mathrm{Y}=22 \mathrm{a}$ & 49.12 \\
\hline & Night & 25 & 24 & 11 & 28 & $\mathrm{Y}=22 \mathrm{a}$ & 49.12 \\
\hline
\end{tabular}

Lower case letters differ for the period (daytime and night) at 5\% - Tukey test; DMI: dry matter intake; RUM: rumination; RES: resting; WAI: water intake; OAC: other activities; $\mathrm{CV}$ : coefficient variation. 
The water intake activity (WAI) had a higher value $(\mathrm{p}<0.05)$ in the daytime period, with no interaction between the analyzed periods (diurnal and nocturnal) and levels DDGS the mean amount of time spent on WAI activity in the different periods (diurnal and nocturnal) were 12 and 5 minutes, respectively. This activity may have been influenced by the climatic conditions and feeding habits of sheep, since the temperature in the daytime period is higher, and consequently the water consumption was higher. According to Araújo et al. (2011), the RUM activity has greater relevance during the daytime period in sheep, and sheep ingest more water to facilitate food swallowing and metabolic processes in both activities. However, as in this experiment the animals remained confined (in metabolism cages), and an artificial light program was used at night, we did not find a similar result.

The inclusion of $0,8,16$, and 24\% DDGS in sheep rations did not change $(\mathrm{p}>0.05)$ the physiological parameters measured (Table 6), such as body temperature of the front (BTF), body temperature of the rear (BTR), and rectal temperature (RET) expressed in ${ }^{\circ} \mathrm{C}$, and respiratory frequency (REF) expressed in motions per minute (mov.min ${ }^{-1}$ ), which had mean values of $32.98{ }^{\circ} \mathrm{C}, 32.64{ }^{\circ} \mathrm{C}, 37.27{ }^{\circ} \mathrm{C}$, and 35.54 mov. $\mathrm{min}^{-1}$, respectively.

A study conducted by Cezar et al. (2004), which evaluated the physiological parameters in sheep of different genetic groups in semi-arid climatic conditions in pastures in northeastern Brazil, found that the mean value of RET was $39.75{ }^{\circ} \mathrm{C}$, and the mean REF was 80.43 mov.min ${ }^{-1}$, regardless of the genetic group. In this study, the values of physiological parameters of sheep were lower than those reported by Cezar et al. (2004), probably due to the different production systems used in the different studies.

The results of RET and REF obtained in the current study are within the range of variation observed in the literature for sheep produced in Brazil. According to Mora et al. (2013), the RET in sheep can range from $39.62{ }^{\circ} \mathrm{C}$ in summer to $37.67{ }^{\circ} \mathrm{C}$ in winter. However, the amplitude of the variation in REF in sheep indicated by the literature is from 28 to 87 mov.min $^{-1}$, during summer and in winter, respectively.

Table 6. Physiological parameters of sheep fed with different levels o of distiller's dried grain with solubles (DDGS) during the 24 hour period.

\begin{tabular}{lcccccc}
\hline Variables & \multicolumn{4}{c}{ Levels of DDGS in experimental rations (\%) } & Regression & \multirow{2}{*}{ \%CV } \\
\cline { 2 - 4 } & 0 & 8 & 16 & 24 & & \\
\hline BTF $\left({ }^{\circ} \mathrm{C}\right)$ & 33.24 & 33.11 & 33.00 & 32.59 & $\mathrm{Y}=32.98$ & 0.95 \\
BTR $\left({ }^{\circ} \mathrm{C}\right)$ & 32.71 & 32.84 & 32.45 & 32.57 & $\mathrm{Y}=32.64$ & 0.50 \\
RET $\left({ }^{\circ} \mathrm{C}\right)$ & 37.27 & 37.25 & 37.42 & 37.13 & $\mathrm{Y}=37.27$ & 0.79 \\
REF $\left(\right.$ mov. min $\left.^{-1}\right)$ & 36.00 & 35.83 & 35.50 & 34.67 & $\mathrm{Y}=35.54$ & 3.15 \\
\hline
\end{tabular}

BTF: Body temperature of the front; BTR: body temperature of the rear; RET: rectal temperature, REF: respiratory frequency.

The physiological parameters of the sheep were not affected $(\mathrm{p}>0.05)$ by the different DDGS inclusion levels in the diets, but the morning and afternoon periods influenced $(p<0.05)$ the results of BTF, BTR, RET, and REF (Table 7). All the physiological parameters evaluated had higher mean values in the afternoon than in the morning. 
Table 7. Physiological parameters of sheep fed with rations containing different levels of distiller's dried grain with solubles (DDGS) in the morning and afternoon period.

\begin{tabular}{|c|c|c|c|c|c|c|c|}
\hline \multirow[t]{2}{*}{ Variables } & \multirow[t]{2}{*}{ Horary } & \multicolumn{4}{|c|}{ Levels of DDGS in experimental rations (\%) } & \multirow[t]{2}{*}{ Average } & \multirow[t]{2}{*}{$\% \mathrm{CV}$} \\
\hline & & 0 & 8 & 16 & 24 & & \\
\hline \multirow[t]{2}{*}{$\operatorname{BTF}\left({ }^{\circ} \mathrm{C}\right)$} & Morning & 32.87 & 32.59 & 32.47 & 32.34 & $\mathrm{Y}=32.57 \mathrm{a}$ & 1.76 \\
\hline & Afternoon & 33.61 & 33.63 & 33.55 & 32.83 & $\mathrm{Y}=33.41 \mathrm{~b}$ & 1.76 \\
\hline \multirow[t]{2}{*}{ BTR $\left({ }^{\circ} \mathrm{C}\right)$} & Morning & 32.49 & 32.49 & 32.08 & 32.07 & $\mathrm{Y}=32.28 \mathrm{a}$ & 1.62 \\
\hline & Afternoon & 32.93 & 33.18 & 32.82 & 33.08 & $\mathrm{Y}=33.00 \mathrm{~b}$ & 1.62 \\
\hline \multirow[t]{2}{*}{$\operatorname{RET}\left({ }^{\circ} \mathrm{C}\right)$} & Morning & 39.92 & 36.75 & 37.04 & 37.21 & $\mathrm{Y}=36.98 \mathrm{a}$ & 1.55 \\
\hline & Afternoon & 37.63 & 37.75 & 37.79 & 37.04 & $\mathrm{Y}=37.55 \mathrm{~b}$ & 1.55 \\
\hline \multirow[t]{2}{*}{ REF (mov. $\min ^{-1}$ ) } & Morning & 34.17 & 34.00 & 33.67 & 33.50 & $\mathrm{Y}=33.83 \mathrm{a}$ & 4.08 \\
\hline & Afternoon & 37.83 & 37.67 & 37.33 & 35.85 & $\mathrm{Y}=37.17 \mathrm{~b}$ & 4.08 \\
\hline
\end{tabular}

Lower case letters differ for the horary (morning and afternoon ) at 5\% - Tukey test; BTF: Body temperature of the front; BTR: body temperature of the rear; RET: rectal temperature, REF: respiratory frequency expressed in movements minutes ${ }^{-1}$.

The mean values of BTF and BTR in sheep fed DDGS in the afternoon were $33.41{ }^{\circ} \mathrm{C}$ and 33.00 ${ }^{\circ} \mathrm{C}$, respectively (Table 7), whereas in the morning the mean values were $32.57{ }^{\circ} \mathrm{C}$ and $32.28{ }^{\circ} \mathrm{C}$. As such, a variation of $2.51 \%$ and $2.18 \%$ was observed, between morning and afternoon in the BTF and BTR, respectively. Furthermore, the RET of the sheep was higher in the afternoon compared to the morning, with mean values of $37.55^{\circ} \mathrm{C}$ and 36.98 ${ }^{\circ} \mathrm{C}$, respectively, probably due to thermoregulation mechanisms.

The values of physiological parameters are correlated with the climatic variables presented in Table 3, where the ambient temperature was 26.17 ${ }^{\circ} \mathrm{C}$ during the morning period, and $31.93{ }^{\circ} \mathrm{C}$ during the afternoon. In addition, the minimum temperature reached during the early morning hours was 23.36 ${ }^{\circ} \mathrm{C}$, and the maximum ambient temperature was $35.19{ }^{\circ} \mathrm{C}$. This fact supports the data obtained (Table 7).

Sheep fed with different levels of DDGS in the diets had REF values of 37.17 mov.min ${ }^{-1}$ during the afternoon, which was higher $(p<0.05)$ than in the morning (33.83 mov.min ${ }^{-1}$, Table 7).
Thus, the existence of a significant difference in these physiological parameters confirms that the performance of sheep in the tropical region of Brazil is related to the mechanisms of thermal homeostasis, and through mechanisms that are sensitive or insensitive to heat.

According to Santos et al. (2006) and Lima et al. (2010), once the temperature of the environment is elevated, it is important to evaluate if animals can dissipate this excessive heat, in efforts to maintain homeothermy. Normally, the effects of variation of climatic factors throughout the day, and the characteristics of the production environment on the animals depends on the efficiency of the mechanisms of sensible heat dissipation such as conduction, convection, and radiation. However, if these mechanisms are not effective, animals use insensitive heat dissipation mechanisms, such as sweating and/or respiratory frequency for homeothermic regulation. According to Lima et al. (2010) and Silva et al. (2015), if the evaporative mechanisms of ruminant animals are not effective, the rectal temperature increases considerably, which characterizes caloric stress. This fact can be 
observed in the current study, where the ambient temperature rose in the afternoon. Thus, sheep had higher RET, REF and THI (Table 3), which characterizes animal stress regarding the production condition, and indicates a risk to the animal's health, and alteration in productive performance.

The inclusion of up to $24 \%$ of distiller's dried grain with solubles in sheep feed in the tropical region of Brazil does not alter ingestive behavior and physiological parameters. Confined sheep raised in a tropical region fed diets containing distiller's dried grain with solubles spent more time ruminating during the night, and spent more time resting and taking in water during the day. In addition, when raising sheep in a tropical environment, more attention should be paid to thermal stress during the afternoon, due to the increase in rectal temperature and respiratory frequency.

\section{Acknowledgements}

Financial support for this research was provided by the "Conselho Nacional de Desenvolvimento Cientifico e Tecnológico - CNPq".

\section{References}

ARAÚJO, G. G. L.; VOLTOLINI, T. V.; TURCO, S. H. N.; PEREIRA, L. G. R. A água nos sistemas de produção de caprinos e ovinos. Petrolina: EMBRAPA Semiárido, 2011. 21 p. Disponível em: <https://www.embrapa.br/ busca-de-publicacoes/-/publicacao/916896/a-agua-nossistema-de-producao-de-caprinos-e-ovinos $>$. Acesso em: 19 abr. 2017.

BIOLOGICAL SCIENCES CURRICULUM STUDY - BSCS/Instituto Nacional para el Mejoramiento de la Enseñanza de las Ciencias - INEC. Biología. Su enseñanza moderna. Buenos Aires: Editorial Estrada, 1970.

BREMM, C.; SILVA, J. H. S.; ROCHA, M. G.; ELEJALDE, D. A. G.; OLIVEIRA NETO, R. A.; CONFORTIN, A. C. Comportamento ingestivo de ovelhas e cordeiras em pastagem de azevém anual sob níveis crescentes de suplementação. Revista Brasileira de Zootecnia, Viçosa, MG, v. 37, n. 12, p. 2097-2106, 2008.
CARVALHO, S.; RODRIGO, M. T.; BRANCO, R. H.; RODRIGUES, C. A. F. Comportamento ingestivo de cabras Alpinas em lactação alimentadas com dietas contendo diferentes níveis de fibra em detergente neutro proveniente da forragem. Revista Brasileira de Zootecnia, Viçosa, MG, v. 35, n. 2, p. 562-568, 2006.

CEZAR, M. F.; SOUZA, B. B.; SOUZA, W. H.; PIMENTA FILHO, E. C.; TAVARES, G. P.; MEDEIROS, G. X. Avaliação de parâmetros fisiológicos de ovinos Doper, Santa Inês e seus mestiços perante condições climáticas do trópico semiárido nordestino. Ciências Agrotécnica, Lavras, v. 28, n. 3, p. 614-620, 2004.

CIRNE, L. G. A.; OLIVEIRA, G. J. C.; JOEGER, S. M. P. L.; BAGALDO, A. R.; LEITE, M. C. P.; ROCHA, N. B.; MACEDO JÚNIOR, C. M.; OLIVEIRA, P. A. Comportamento ingestivo de cordeiros em confinamento, alimentados com dietas exclusiva de concentrado com diferentes porcentagens de proteína. Arquivo Brasileiro de Medicina Veterinária e Zootecnia, Belo Horizonte, v. 66, n. 1, p. 229-234, 2014.

DESWYSEN, A. G.; DUTILLEUL, P. A.; GODFRIN, J. P. Nycterohemeral eating and ruminanting patterns in heifers fed grass or corn silage: analysis by finite fourier transform. Journal of Animal Science, Champaign, v. 71, n. 10 , p. 2739-2747, 1993.

FERREIRA, F.; CAMPOS, W. E.; CARVALHO, A. U.; PIRES, M. F. A.; MARTINEZ, M. L.; SILVA, M. V. G. B.; VERNEQUE, R. S.; SILVA, P. F. Parâmetros clínicos, hematológicos e hormonais de bovinos submetidos ao estresse calórico. Arquivo Brasileiro de Veterinária e Zootecnia, Goiânia, v. 61, n. 4, p. 769-776, 2009.

FISCHER, V.; DESWYSEN, A. G.; AMOUCHE, E.; LOBATO, J. F. P. Efeitos da pressão de pastejo sobre o comportamento ingestivo e o consumo voluntário de ovinos em pastagem. Revista Brasileira de Zootecnia, Viçosa, MG, v. 26, n. 5, p. 1025-1031, 1997a.

FISCHER, V.; DESWYSEN, A. G.; DESPRES, L.; DUTILLEUL, E.; LOBATO, J. F. P. Comportamento ingestivo de ovinos recebendo dieta à base de feno durante um período de seis meses. Revista Brasileira de Zootecnia, Viçosa, MG, v. 26, n. 5, p. 1032-1038, 1997 b.

GERON, L. J. V.; COSTA, F. G.; GARCIA, J.; ZANINE, A. M.; OLIVEIRA, E. B.; CABRAL, L. S.; PIERANGELI, M. A. P.; AGUIAR, S. C. Nutrients intake and digestibility in sheep fed with residue from the extraction of tamarindo pulp. Semina: Ciências Agrárias, Londrina, v. 36, n. 6, p. 4401-4412, 2015. Supplement 2.

GERON, L. J. V.; GARCIA, J.; COELHO, K. S. M.; AGUIAR, S. C.; ZANINE, A. M.; SOUZA, A. L.; CARVALHO, J. T. H.; ROBERTO, L. S.; SOUSA 
NETO, E. L.; FERREIRA, D. J. In vitro digestibility and nutritional characterization of distillers dried grains with solubles according to the Cornell Net carbohydrate and protein system. Semina: Ciências Agrárias, Londrina, v. 38, n. 2, p. 1230-1238, 2017a.

GERON, L. J. V.; GARCIA, J.; ZANINE, A. M.; AGUIAR, S. C.; SOUSA NETO, E. L.; PAULA, E. J. H.; DINIZ, L. C.; ROBERTO, L. S.; COELHO, K. S. M.; SANTOS, I. S.; CARVALHO, J. T. H.; PALERMO NETO, F. Consumo, digestibilidade dos nutrientes e parâmetros ruminais em ovinos alimentados com rações contendo grão seco de destilaria com solúveis. Boletim de Industria Animal, Nova Odessa, v. 74, n. 2, p. 340$349,2017 \mathrm{~b}$

GERON, L. J. V.; MEXIA, A. A.; CRISTO, R. L.; GARCIA, J.; CABRAL, L. S.; TRAUTMANN, R. J.; MARTINS, O. S.; ZEOULA, L. M. Consumo, digestibilidade dos nutrientes e características ruminais de cordeiros alimentos com níveis crescentes de concentrado em ambiente tropical no Vale do alto Guaporé - MT. Semina: Ciências Agrárias, Londrina, v. 34, n. 5, p. 2497-2510, 2013.

GERON, L. J. V.; ZEOULA, L. M.; YOSHIMURA, E. H.; FRANCO, S. L.; CHIQUITELLI NETO, M.; PAULA, E. M.; SAMENSARI, R. B.; PERES, L. P. Comportamento ingestivo de novilhas Nelore em pastejo recebendo suplemento a base de própolis ou monensina sódica. Semina: Ciências Agrárias, Londrina, v. 35, n. 4, p. 20147-2060, 2014.

HEMSWORTH, P. H.; BARNETT, J. L.; BEVERIDGE, L. The welfare of extensively managed dairy cattle a review. Applied Animal Behaviour Science, London, v. 42, n. 2, p. 161-182, 1995.

JOHNSON, T. R.; COMBS, D. K. Effects of prepartum diet, inert rumen bulk, and dietary polythylene glicol on dry matter intake of lactating dairy cows. Journal of Dairy Science, Champaign, v. 74, n. 4, p. 933-944, 1991.

HUBNER, C. H.; PIRES, C. C.; GALVANI, D. B.; CARVALHO, S.; JOCHIMS, F.; WOMMER, T. P.; GASPERIN, B. G. Comportamento ingestivo de ovelhas em lactação alimentadas com dietas contendo diferentes níveis de fibra em detergente neutro. Ciência Animal, Goiânia, v. 38, n. 4, p. 1078-1084, 2008.

LIMA, C. C. V.; SILVA, D. F. M.; COSTA, J. N.; COSTA NETO, A. O.; SOUZA, T. S. Parâmetros fisiológicos de cordeiros mestiços (1/2 e 3/4Dorper) do nascimento até os 90 dias de idade. Revista Brasileira de Saúde e Produção Animal, Salvador, v. 11, n. 2, p. 354-361, 2010.

MILLEN, D. D.; RONCHESEL, J. R.; PARRA, F. S.; PACHECO, R. D. L.; MARTINS, C. L.; ARRIGONI, M.
B. Anticorpos policlonados em dietas com alta inclusão de concentrado para bovinos confinados. Ciência Rural, Santa Maria, v. 43, n. 9, p. 1660-1667, 2013.

MICHAILOFF, A. A.; DAMO, B.; ROMANI, P.; SILVEIRA, M. F.; MAEDA, E.; WLODARKI, L.; FRANCISCO, L. F.; PROHMANN, G. Comportamento ingestivo e avaliação térmica de ovinos confinados. In: CONGRESSO BRASILEIRO DE ZOOTECNIA ZOOTEC, 25., 2015, Fortaleza. Anais... Fortaleza: Associação Brasileira de Zootecnistas, 2015. p. 1-3.

MORA, N. H. A.; QUEIROZ, E. O.; MACEDO, F. A. F.; BARBOSA, O. R.; SANTANA, T. E. Z. Parâmetros fisiológicos e índice de conforto térmico para ovelhas da raça Santa Inês durante verão e inverno no Noroeste do Paraná. Synergismus Scyentifica, Pato Branco, v. 8, n. 2, p. 1-6, 2013.

MOUSQUER, C. J.; FERNANDES, G. A.; CASTRO, W. J. R.; HOFFMANN, A.; SIMIONI, T. A.; FERNANDES, F. F. D. Comportamento ingestivo de ovinos confinados com silagens. Revista Brasileira de Higiene e Sanidade Animal, Fortaleza, v. 7, n. 2, p. 301-322, 2013.

NATIONAL RESEARCH COUNCIL - NRC. Nutrient requirements of small ruminants: sheep, goats, cervids, and New World camelids. Washington: National Academy Press, 2007. 384 p.

NUEZ-ORTÍN, W. G.; YU, P. Nutrient variation and availability of wheat DDGS, corn DDGS and blend DDGS from bioethanol plants. Journal of the Science of Food and Agriculture, London, v. 89, n. 7, p. 1754-1761, 2009.

RIBEIRO, E. L. A.; MIZUBUTI, I. Y.; SILVA, L. D. F.; PAIVA, F. H. P.; SOUSA, C. L.; CASTRO, F. A. B. Desempenho, comportamento ingestivo e características de carcaça de cordeiros confinados submetidos a diferentes frequências de alimentação. Revista Brasileira de Zootecnia, Viçosa, MG, v. 40, n. 4, p. 892-898, 2011.

SALIM, H. M.; KRUK, Z. A.; LEE, B. D. Nutritive value of corn distillers dried grains with solubles as na ingredient of poultry diets: a review. World's Poultry Science Journal, Cambridge, v. 66, n. 2, p. 411-432, 2010.

SANTOS, J. R. S.; SOUZA, B. B.; SOUZA, W. H.; CEZAR, M. F.; TAVARES, G. P. Respostas fisiológicas e gradientes térmicos de ovinos das raças Santa Inês, Morada Nova e de seus cruzamentos com a raça Dorper às condições do Semiárido nordestino. Ciências Agrotécnicas, Lavras, v. 30, n. 5, p. 995-1001, 2006.

SILVA, A. L.; SANTANA, M. L. A.; SOUSA, P. H. A. A.; ALMEIDA JÚNIOR, T. F.; FARIAS, L. A.; SOUSA JÚNIOR, S. C. Avaliação das variáveis fisiológicas 
de ovinos Santa Inês sob influência do ambiente semiárido piauiense. Journal of Animal Behaviour and Biometeorology, Mossoró, v. 3, n. 2, p. 69-72, 2015.

SILVA, D. J.; QUEIROZ. A. C. Análise de alimentos: métodos químicos e biológicos. 2. ed. Viçosa, MG: UFV, 2002. $178 \mathrm{p}$.

SILVA JUNIOR, A. M.; SILVA, T. P. D.; PEREIRA, A. M.; VIANA, G. E. N.; SAMPAIO, K. H.; MARQUES, C. A. T.; COSTA, A. P. R. Efeitos de turno e de raça sobre os parâmetros fisiológicos de ovelhas deslanadas em confinamento no sul do estado de Piaui. Acta Tecnologica, Teresina, v. 9, n. 1, p. 21-25, 2014.

SNIFFEN, C. J.; O'CONNOR, J. D.; VAN SOEST, P. $\mathrm{J}$. A net carbohydrate and protein system for evaluating cattle diets II. Carbohydrate and protein availability. Journal of Animal Science, Champaign, v. 70, n. 11, p. 3562-3577, 1992.

SOUZA, A.; PAVÃO, H. G.; LASTORIA, G.; GABAS, S. G.; CAVAZZANA, G. H.; PARANHOS FILHO, A. C. Um estudo de conforto e desconforto térmico para o mato grosso do Sul. Revista de Estudos Ambientais, Blumenau, v. 12, n. 2, p. 15-25, 2010.

SOUZA, O. M.; MARTINS, E. N.; ROSSI, R. M.; OLIVEIRA, C. A. L.; AGUIAR, S. C.; PAULA, E. J. H.; GERON, L. J. V.; STIVANIN, T. E.; FERREIRA, E. B. Ruminal $\mathrm{pH}$ and $\mathrm{N}-\mathrm{NH}_{3}$ behavior: a Bayesian approach. Semina: Ciências Agrárias, Londrina, v. 37, n. 1, p. 311320, 2016.

SPHIES, M. J.; WHITNEY, M. H.; SHURSON, G. C. Nutrient database for distiller's dried grains with solubles produced from new ethanol plants in Minnesota and South Dakota. Journal of Animal Science. Champaign, v. 80, n. 8, p. 2639-2643, 2002.
THOM, E. C. The discomfort index. Weatherwise, San Diego, v. 60, n. 1, p. 12-57, 1959.

UNIVERSIDADE FEDERAL DE VIÇOSA - UFV. Sistemas de análises estatísticas e genéticas - SAEG. Versão 9. 1. Manual do usuário. Viçosa, MG: Imprensa Universitária, 2007. 150 p.

VALADARES FILHO, S. C.; MACHADO, P. A. S.; CHIZZOTTI, M. L.; AMARAL, H. F.; MAGALHÃES, K. A.; ROCHA JÚNIOR, V. R.; CAPELLE, E. R. Tabelas brasileiras de composição de alimentos para bovinos. 3 . ed. Viçosa, MG: UFV/DZO, 2010. 502 p.

VAN SOEST, P. J. Nutritional ecology of the ruminant. $2^{\text {th }}$ ed. Ithaca: Cornell University Press, 1994. 476 p.

VAN SOEST, P. J.; ROBERTSON, J. B.; LEWIS, B. A. Methods for dietary fiber, neutral detergent fiber, and nonstarch polysaccharides in relation to animal nutrition. Journal of Dairy Science, Champaign, v. 74, n. 12, p. 3583-3597, 1991.

VERÍSSIMO, C. J.; TITTO, C. G.; KATIKI, L. M.; BUENO, M. S.; CUNHA, E. A.; MOURÃO, G. B.; OTSUK, I. P.; PEREIRA, A. M. F.; NOGUEIRA FILHO, J. C. M.; TITTO, E. A. L. Tolerância ao calor em ovelhas Santa Inês de pelagem clara e escura. Revista Brasileira de Saúde e Produção Animal, Salvador, v. 10, n. 1, p. 159-167, 2009.

YANG, W. Z.; BEAUCHEMIM, K. A.; RODES, L. A. Effects of grain processing, forage to concentrate ration, and forage particle size on rumen $\mathrm{pH}$ and digestion by dairy cattle. Journal of Dairy Science, Champaign, v. 84, n. 2, p. 203-216, 2001. 